\title{
PROSPEK PERKEMBANGAN MODAL KOPERASI BAITUL MAAL WAT TAMWIL SERUYAN SEJAHTERA
}

\author{
Rinto Alexandro ${ }^{1)}$, Tonich $\mathrm{Uda}^{2)}$ \\ Program Studi Pendidikan Ekonomi, Fakultas Keguruan dan Ilmu Pendidikan, \\ Universitas Palangka Raya, Indonesia \\ rinto.alexandro@fkip.upr.ac.id
}

\begin{abstract}
Baitul Maal Cooperative Wat Tamwil Seruyan Sejahtera which addresses at Jalan Patimura, Kuala Pembuang 1, Seruyan Regency. This cooperative was formed on November 2, 2012 with a cooperative legal entity No: 124 / BH / XVIII.14 / IDKUMKM / 11/2012 and chaired by Ir. H. Tarwidi Tamasaputra. This study uses a qualitative approach that is descriptive analysis, with data collection techniques used are observation, interviews and documentation as well as the type of data used is time series data. The data obtained will be analyzed by the growth equation and least square trand. Based on the results of the study note that the capital development Based on the analysis in table 5 can be seen in 2013 there was a growth of 15\%, but a decline in 2014 amounted to 17\%. Growth that greatly increased in 2015 was $40 \%$ which was affected by the increase in membership. Whereas growth in 2016 was only $16 \%$. The average capital growth of the Cooperative Baitul Maal wat Tamwil Seruyan Sejahtera in 2012-2016 is $9.62 \%$. While based on table 7 it can be seen that the results of capital development forecasts at the Baitul Maal wat Tamwil Seruyan Sejahtera cooperative in 2017 amounted to Rp 396,035,361.60, in 2018 amounted to IDR 422,391,710.70, in 2019 amounted to IDR 448,748.059.80, in 2020, IDR 475,104,408.90 and in 2021 IDR 501,460,758.00. This forecast of development tends to increase from year to year in the amount of IDR 26,356,349.10. This increase was affected by the business carried out, the addition of new members and by voluntary contributions from members.
\end{abstract}

Keywords: Development OfCooperative Capital

\begin{abstract}
Abstrak
Koperasi Baitul Maal Wat Tamwil Seruyan Sejahtera yang beralamatkan di Jalan Patimura, Kuala Pembuang 1, Kabupaten Seruyan. Koperasi ini dibentuk pada tanggal 02 Nopember 2012 dengan badan hukum koperasi No: 124/BH/XVIII.14/IDKUMKM/ 11/2012 dan diketuai oleh Ir. H. Tarwidi Tamasaputra. Penelitian ini menggunakan pendekatan kualitatif yang bersifat deskriptif analisis, dengan teknik pengumpulan data yang digunakan adalah observasi, wawancara dan dokumentasi serta jenis data yang digunakan merupakan data time siries. Data yang didapatkan akan dianalisis dengan persamaan growth dan trand least square. Berdasarkan hasil penelitian diketahui bahwa perkembangan modal berdasarkan analisis pada tabel 5 dapat dilihat pada tahun 2013 terjadi pertumbuhan sebesar 15\%, tapi terjadi penurunan pada tahun 2014 sebesar 17\%. Pertumbuhan yang sangat meningkat pada tahun 2015 yaitu sebesar $40 \%$ yang terpengaruh oleh pertambahan anggota. Sedangkan pertumbuhan pada tahun 2016 hanya 16\%. Rata-rata pertumbuhan modal Koperasi Baitul Maal wat Tamwil Seruyan Sejahtera tahun 2012-2016 yaitu sebesar 9,62\%. Sedangkan berdasarkan tabel 7 dapat dilihat bahwa hasil ramalan perkembangan modal pada koperasi Baitul Maal wat Tamwil Seruyan Sejahtera pada tahun 2017 sebesar Rp 396.035.361,60, tahun 2018 sebesar Rp 422.391.710,70, tahun 2019 sebesar Rp 448.748.059,80, tahun 2020 sebesar Rp 475.104.408,90 dan tahun 2021 sebesar Rp 501.460.758,00. Ramalan perkembangan ini cenderung makin meningkat dari tahun ke tahun yaitu sebesar $\mathrm{Rp} 26.356 .349,10$. Peningkatan ini terpengaruh dari usaha yang dijalankan, penambahan anggota baru serta oleh sumbangan sukarela dari anggota.
\end{abstract}

Kata Kunci: Perkembangan Modal Koperasi 


\section{PENDAHULUAN}

Pembukaan Undang-Undang Dasar 1945 menegaskan bahwa salah satu tujuan negara Indonesia adalah memajukan kesejahteraan umum, baik material maupun spiritual. Pembangunan nasional merupakan pembangunan seluruh masyarakat Indonesia di segala bidang. Dari pembangunan ini diharapkan dapat tercipta suatu keadilan dan kemakmuran yang merata bagi seluruh rakyat Indonesia. Pasal 33 Undang-Undang Dasar 1945 ayat (1) menyatakan bahwa "perekonomian disusun sebagai usaha bersama berdasar atas asas kekeluargaan”. Selanjutnya di dalam penjelasan pasal 33 tercantum dasar demokrasi, produksi dikerjakan oleh semua, untuk semua di bawah pimpinan atau pemilikan anggota masyarakat. Kemakmuran masyarakatlah yang diutamakan, bukan kemakmuran orang seorang. Oleh karena itu, bangun perusahaan yang sesuai dengan itu adalah koperasi. Pembangunan koperasi sebagai wadah ekonomi rakyat diarahkan agar makin memiliki kemampuan menjadi badan usaha yang efisien dan menjadi gerakan ekonomi rakyat yang sehat, tangguh, kuat dan mandiri serta berakar dalam masyarakat. Koperasi adalah perkumpulan orang, biasanya yang memiliki kemampuan ekonomi terbatas, yang melalui suatu bentuk organisasi perusahaan yang diawasi secara demokratis, masing-masing memberikan sumbangan yang setara terhadap modal yang diperlukan, dan bersedia menanggung resiko serta menerima imbalan yang sesuai dengan usaha yang mereka lakukan. (ILO dalam Subandi, 2009:18)

Koperasi sebagai bagian dari perekonomian nasional diharapkan menjadi badan usaha yang mampu berperan di semua bidang usaha, terutama dalam kehidupan ekonomi rakyat dalam mewujudkan demokrasi ekonomi.

Berdasarkan Undang-Undang perkoperasian Nomor 25 tahun 1992 pasal 1 dijelaskan koperasi merupakan badan usaha yang beranggotakan orang atau badan hukum koperasi dengan melandaskan kegiatannya berdasarkan prinsip koperasi sekaligus sebagai gerakan ekonomi rakyat yang berdasarkan atas asas kekeluargaan.

Koperasi merupakan gerakan ekonomi rakyat yang bertujuan untuk meningkatkan kesejahteraan masyarakat dengan melandaskan kegiatannya pada prinsip-prinsip koperasi. Sebagai gerakan koperasi menjunjung tinggi nilai-nilai kebersamaan dan kerja sama antar anggotanya, yang sangat diperlukan untuk mewujudkan tujuan utamanya yaitu meningkatkan kesejahteraan para anggotanya dan kemakmuran masyarakat.

Rencana Pembangunan Jangka Panjang Daerah (RPJPD) Kabupaten Seruyan 20052025 merupakan pedoman dalam penyusunan visi, misi dan program Kepala Daerah. RPJPD Kabupaten Seruyan juga menjadi pedoman penyelenggaraan pemerintahan, pembangunan, dan pelayanan masyarakat Seruyan dalam pelaksanaan otonomi daerah yang nyata, dinamis, serasi, dan bertanggung jawab dalam kurun waktu 20 tahun sampai dengan tahun 2025. Berdasarkan misi ke 8 Kabupaten Seruyan yaitu: Meningkatkan kemampuan dan pengembangan pertumbuhan perekonomian rakyat dengan mendorong pengembangan ekonomi rakyat utamanya, industri kecil, industri rumah tangga, perdagangan dan jasa serta koperasi. (http://www.seruyankab.go.id/index.php/ publik/artikel-daerah/113).

Kabupaten Seruyan merupakan Kabupaten yang sedang giat-giatnya melakukan pengembangan perekonomian baik lewat industri, koperasi dan UMKM. Hal ini terlihat dari data Dinas Perindustrian Perdagangan Koperasi dan UMKM (Disperindagkop) Seruyan, jumlah koperasi yang aktif hingga Oktober 2019 sebanyak 211 unit dengan jumlah anggota 25.689 orang. Dengan modal 
keseluruhan mencapai hampir Rp 12 miliar tapi mengalami penurunan pertumbuhan $51,62 \%$ pada tahun 2019 .

Penurunan pertumbuhan permodalan ini tidak terjadi pada seluruh koperasi yang ada di Kabupaten Seruyan. Salah satunya yaitu Koperasi Baitul Maal Wat Tamwil Seruyan Sejahtera yang dapat dilihat data permodalannya pada tabel 1 di bawah ini.

Tabel 1. Perkembangan koperasi Baitul Maal Wat Tamwil Seruyan Sejahtera.

\begin{tabular}{cccccr}
\hline No & Tahun & $\begin{array}{c}\text { Jumlah } \\
\text { Anggota }\end{array}$ & Modal & Sisa Hasil Usaha \\
\hline 1 & 2012 & 07 & Rp 197.666.116,00 & Rp $48.060 .978,00$ \\
2 & 2013 & 14 & Rp 226.815.332,00 & Rp $56.137 .803,00$ \\
3 & 2014 & 18 & Rp 189.292.375,00 & Rp $93.136 .846,00$ \\
4 & 2015 & 36 & $R p 292.775 .969,00$ & Rp 105.108.861,00 \\
5 & 2016 & 42 & Rp 312.998.543,00 & Rp 122.626.780,00 \\
\hline
\end{tabular}

Koperasi Baitul Maal Wat Tamwil Seruyan Sejahtera merupakan sebuah koperasi yang berdiri pada tanggal 02 Nopember 2012 di Jalan Patimura, Kuala Pembuang 1, Kabupaten Seruyan. Koperasi ini dibentuk dengan badan hukum koperasi No: 124/BH/XVIII.14/IDKUMKM/11/2012 dan diketuai oleh Ahmad Suheli, S.Pd. Setelah berdiri beberapa tahun terjadi penurunan pertumbuhan modal koperasi yang ada di Kabupaten Seruyan tetapi Koperasi Baitul Maal Wat Tamwil Seruyan Sejahtera ini mampu bertahan hingga sampai saat ini.

\section{METODE PENELITIAN}

\section{Pendekatan Penelitian}

Pendekatan kualitatif dalam hal ini sesungguhnya adalah prosedur penelitian yang menghasilkan data-data deskriptif berupa kata-kata tertulis atau lisan dari orangorang dan perilaku yang dapat diamati. Sehingga data yang dikumpulkan adalah data yang berupa kata/kalimat maupun gambar (bukan angka-angka). Data-data ini bisa berupa naskah wawancara, catatan lapangan, foto, video, dokumen pribadi, memo ataupun dokumen resmi lainnya (Maleong, 2002: 46).

\section{Sumber Data}

Sumber data dibagi menjadi dua yaitu data primer dan data sekunder yaitu:

\section{Data Primer}

Merupakan sumber data penelitian yang diperoleh secara langsung dari sumber asli (tidak melalui media perantara). Data primer secara khusus dikumpulkan oleh peneliti untuk menjawab pertanyaan penelitian. Data ini berupa opini subyek (orang) secara individual atau kelompok, atau observasi terhadap suatu benda (fisik), kejadian atau kegiatan, dan hasil pengujian. Peneliti mengumpulkan data sesuai dengan yang diinginkan, karena data yang tidak relevan dengan tujuan penelitian dapat dieliminir atau setidaknya dikurangi.

\section{Data sekunder}

Merupakan sumber data penelitian yang diperoleh peneliti secara tidak langsung melalui media perantara (diperoleh dan dicatat pihak lain). Data sekunder umumnya berupa bukti, catatan atau laporan historis yang telah tersusun dalam arsip (data dokumenter) yang dipublikasikan dan yang tidak dipublikasikan.

Dari pengertian di atas sumber data yang digunakan dalam penelitian ini adalah data sekunder yaitu data yang ditentukan oleh peneliti sendiri secara langsung dari obyek penelitian, dalam hal ini cara yang diperoleh, diamati, dicatat kemudian diambil kesimpulannya mengenai perkembangan modal usaha koperasi Baitul Maal wat Tamwil Seruyan Sejahtera dan data lainnya seperti data mengenai sejarah singkat berdirinya koperasi, struktur organisasi, personalia, daftar inventaris, dan proses pelaksanaan pembangunan.

\section{Teknik Pengumpulan Data}

Prosedur pengumpulan data dalam penelitian ini menggunakan tiga teknik pengumpulan data yaitu observasi, wawancara dan dokumentasi. 


\section{Observasi}

Observasi merupakan pengamatan yang dilakukan peneliti untuk mengamati objek yang akan diteliti secara langsung. "Observasi (observation) merupakan teknik atau pendekatan untuk mendapatkan data primer dengan cara mengamati langsung objek data". (Jogiyanto, 2015: 109). Observasi merupakan suatu proses yang komplek, suatu proses yang tersusun dari berbagai proses biologis dan psikologis". (Sutrisno Hadi dalam Sugiono, 2013: 203) Observasi merupakan pengamatan langsung terjun ke lapangan yang dilakukan oleh peneliti, sehingga peneliti lebih dekat, memahami, bahkan ikut serta di dalam objek yang akan diteliti yang diharapkan adalah data yang didapat oleh peneliti dapat dipercaya dan dipertanggung jawabkan. Peneliti menggunakan instrumen observasi sebagai salah satu teknik pengumpulan data, agar peneliti dapat memperoleh informasi maupun data yang sesuai dengan permasalahan yang akan diangkat dalam penelitian dan yang akan dianalisis oleh peneliti.

\section{Wawancara}

Teknik wawancara juga merupakan teknik percakapan dengan maksud tertentu. Teknik ini dilakukan dengan cara mengadakan wawancara dengan berbagai sumber data yang dapat memberikan informasi atau data. wawancara digunakan sebagai teknik pengumpulan data apabila peneliti ingin melakukan studi pendahuluan untuk menemukan permasalahan yang harus diteliti, tetapi juga apabila peneliti ingin mengetahui hal-hal dari responden yang lebih mendalam. (Sugiyono, 2009: 317). Wawancara yang peneliti gunakan dalam penelitian kali ini adalah sebagai pendukung atau pelengkap dari metode dokumentasi. Di mana peneliti telah merancang berbagai macam pertanyaan yang akan diajukan ketika proses wawancara berlangsung. Wawancara dilakukan agar peneliti mendapatkan informasi dari narasumber-narasumber yang terpercaya guna mendukung data dokumentasi yang diperoleh.

\section{Dokumentasi}

Dokumen merupakan catatan peristiwa yang sudah berlalu. Dokumen bisa berbentuk tulisan, gambar, atau karya-karya monumental dari seseorang". (Sugiyono, 2009: 329). Studi dokumentasi merupakan suatu teknik pengumpulan data dengan cara mempelajari dokumen untuk mendapatkan data atau informasi yang berhubungan dengan masalah yang diteliti. Studi dokumentasi dalam penelitian ini adalah dengan meminta data-data dari pihak koperasi. Misalnya saja, susunan pengurus koperasi, struktur organisasi, sumber modal, dan lainlainnya. Hal ini dilakukan agar informasi yang didapatkan benar-benar bersumber dari objek yang dijadikan sebagai tempat penelitian. Teknik dokumentasi pun dilakukan dalam bentuk memotret semua kejadian yang berlangsung selama peneliti melakukan kegiatan penelitian.

\section{Analisis Data}

Jenis data yang digunakan dalam penelitian ini adalah Data time series. "Data time series adalah data yang terdiri dari satu objek namun terdiri dari beberapa waktu periode, seperti harian, bulanan, triwulanan, dan tahunan". (Elsi Marsilia, 2015). Misalnya: data pertumbuhan PDB dari tahun 2009 sampai 2013 (objeknya hanya satu: pertumbuhan PDB triwulanan, namun disajikan dalam beberapa periode: dari tahun 2009-2013 secara triwulan). Data ini nantinya akan diamati trend atau pola perubahannya dari tahun ke tahun (berurutan), sehingga data ini dikatakan sebagai data historis atau runtun waktu. Pola perubahan atau trend pada waktuwaktu lampau tersebut akan dapat digunakan untuk mengestimasi pola perubahan pada tahun-tahun atau waktu mendatang.

Sesuai dengan tujuan penelitian yang ingin mengetahui perkembangan modal 
usaha Koperasi Baitul Maal Wat Tamwil Seruyan Sejahtera maka penulis akan mengumpulkan data mengenai perkembangan modal usaha. Data keuangan dari tahun 2012-2016 yang akan menjadi dasar peramalan perkembangan modal usaha. Sedangkan, untuk perkembangan modal usaha yang akan diramal yaitu pada tahun 2017-20121.

Data keuangan dari tahun 2012-2016 akan dianalisis dengan menggunakan rumus Growth. Rumus Growth adalah suatu persamaan yang digunakan untuk menghitung tingkat pertumbuhan. Rumus Growth yaitu sebagai berikut:

1. Rumus Tingkat Pertumbuhan

$$
\text { Growth }=\frac{X_{n}-X_{0}}{X_{0}} \times 100 \%
$$

2. Rumus rata-rata pertumbuhan

Growth Rate $=\left(\mathrm{X}_{\mathrm{n}}: \mathrm{X}_{0}\right)^{1: \mathrm{n}}-1 \mathrm{X} 100 \%$

Keterangan:

Growth = tingkat pertumbuhan

Growth Rate $=$ rata-rata pertumbuhan

$\mathrm{X}_{\mathrm{n}}=$ modal akhir $/$ tahun berjalan

$\mathrm{X}_{0}=$ modal awal / tahun sebelumnya

${ }^{\mathrm{n}}=$ rentan waktu

(Ahmad Sawir, 2001:46)

Sedangkan untuk data peramalan perkembangan tahun 2017-2021 akan dianalisis dengan menggunakan Analisis Trend Least Square merupakan suatu metode analisis yang ditujukan untuk melakukan suatu estimasi atau peramalan pada masa yang akan datang. Untuk melakukan peramalan dengan baik maka dibutuhkan berbagai macam informasi (data) yang cukup banyak dan diamati dalam periode waktu yang relatif cukup panjang, sehingga dari hasil analisis tersebut dapat diketahui sampai berapa besar fluktuasi yang terjadi dan faktor-faktor apa saja yang mempengaruhi terhadap perubahan tersebut. Secara teoristis, dalam analisis time series yang paling menentukan adalah kualitas atau keakuratan dari informasi atau data-data yang diperoleh serta waktu atau periode dari data-data tersebut dikumpulkan.

Jika data yang dikumpulkan tersebut semakin banyak maka semakin baik pula estimasi atau peramalan yang diperoleh. Sebaliknya, jika data yang dikumpulkan semakin sedikit maka hasil estimasi atau peramalannya akan kurang baik. Adapun persamaan Trend Least Square sebagai berikut:

$$
\mathrm{Y}=\mathrm{a}+\mathrm{bX}
$$

Dimana:

$$
\begin{aligned}
& \mathrm{a}=\frac{\Sigma \mathrm{Y}}{\mathrm{N}} \\
& \mathrm{b}=\frac{\Sigma \mathrm{XY}}{\Sigma \mathrm{X}^{2}}
\end{aligned}
$$

Keterangan :

$\mathrm{Y}=$ perkembangan yang diramal

$\mathrm{X}=$ variabel waktu (tahun)

$\mathrm{a}=$ tingkat penjualan yang dianggap konstan

$\mathrm{b}=$ tingkat permintaan atau dianggap berubah

$\mathrm{n}=$ jumlah tahun yang diteliti

(Selamet Sentoso, 2008).

\section{HASIL DAN PEMBAHASAN}

Secara kelembagaan Koperasi Baitul Maal wat Tamwil Seruyan Sejahtera telah memenuhi standar sebagai sebuah organisasi Bisnis dan Sosial yang bersaing dengan lembaga-lembaga yang mempunyai pangsa pasar sama. Sejak terselenggaranya rapat awal pada tanggal 20 September 2012 di rumah bapa Ir. H. Tarwidi Tamasaputra sebagai ketua. Kegiatan selanjutnya adalah pemenuhan standar organisasi yang berbadan hukum dengan mengacu pada UU RI Nomor 251992 koperasi telah mendapatkan Badan Hukum dari kantor Notaris Marjoni 
Zainuddin $\mathrm{SH}, \mathrm{MH}$, dengan nomor 02 tanggal 02 Nopember 2012.

Agar Koperasi Baitul Maal wat Tamwil Seruyan Sejahtera mendapat legalitas dari pemerintah, maka pengurus telah mempersiapkan berkas persyaratan untuk mendapatkan Akte Badan Hukum. Sehingga pada tanggal 02 Nopember 2012 Koperasi Baitul Maal wat Tamwil Seruyan Sejahtera telah disahkan oleh Menteri Koperasi Usaha Mikro Kecil dan Menengah untuk memperoleh Badan Hukum dengan No: 124/BH/XVIII/ IDKUMKM/11/2012.

Usaha yang dikelola Koperasi Baitul Maal wat Tamwil Seruyan Sejahtera adalah sebagai berikut:

a. Jasa layanan simpanan

1) Simanis (simpanan anak-anak islam)

2) Simpedu (simpanan peduli umat)

3) Sididik (simpanan pendidikan)

4) Sidul (simpanan Idul Fitri)

5) Simanja (simpanan berjangka dengan 6 bulan dan 12 bulan)

6) Simpanan wajib pembiayaan

7) Simpanan wakab

b. Jasa layanan pembiayaan

1) Pembiayaan mudharobah

2) Pembiayaan murabahah

3) Pembiayaan al ujroh

4) Pembiayaan istijaroh/sewa

c. Sektor riil

1) Penjualan rumah KPR

2) Penjualan kapling tanah

\section{Sumber Modal}

Sumber modal Koperasi Baitul Maal wat Tamwil Seruyan Sejahtera berasal dari modal sendiri dan modal pinjaman adalah sebagai berikut:

\section{a. Modal Sendiri}

Modal sendiri Koperasi Baitul Maal wat Tamwil Seruyan Sejahtera berasal dari simpanan pokok anggota yang disetorkan sebagai syarat bergabungnya sebagai anggota koperasi dan menjadi setoran setiap tahun.
Serta simpanan wajib yang harus disetorkan setiap bulannya yang besarannya sesuai hasil Rapat Anggota dan simpanan sukarela sesuai kemampuan anggota masing-masing yang besarannya tidak ditentukan batasanbatasannya. Untuk lebih jelasnya dapat dilihat pada tabel 2 berikut ini:

Tabel 2. Modal sendiri Koperasi Baitul Maal wat Tamwil Seruyan Sejahtera

\begin{tabular}{|c|c|c|c|}
\hline No & Keterangan & Bulan/orang & Tahun/orang \\
\hline 1 & $\begin{array}{c}\text { Simpanan } \\
\text { pokok anggota }\end{array}$ & & Rp $10.000,00$ \\
\hline 2 & $\begin{array}{l}\text { Simpanan } \\
\text { wajib }\end{array}$ & Rp 5.000,00 & \\
\hline 3 & $\begin{array}{c}\text { Simpanan } \\
\text { sukarela }\end{array}$ & $\begin{array}{l}\times \text { Sesuai } \\
\text { kemampuan } \\
\text { anggota }\end{array}$ & $\begin{array}{l}\times \text { sesuai } \\
\text { kemampuan } \\
\text { anggota }\end{array}$ \\
\hline
\end{tabular}

Sumber: Rapat anggota tahunan Koperasi Baitul Maal wat Tamwil Seruyan Sejahtera.

\section{b. Modal Pinjaman}

Dalam permodalan awal Koperasi Baitul Maal wat Tamwil Seruyan Sejahtera mendapatkan pendanaan dari KJKS KUBE Sejahtera 068 Sampit sebesar Rp 138.740.000,00 dana tersebut belum termasuk biaya pendidikan dan pelatihan anggota Koperasi Baitul Maal wat Tamwil Seruyan Sejahtera di koperasi tersebut.

\section{Hasil Analisis Data}

Seperti yang telah dikemukakan dalam rumusan masalah penelitian ini yaitu ingin mengetahui Bagaimana perkembangan modal Koperasi Baitul Maal wat Tamwil Seruyan Sejahtera. Untuk mengetahui perkembangan masa yang akan datang, yaitu dari tahun 2017-2021 tersebut harus mengadakan perhitungan terhadap data permodalan dari tahun 2012-2016.

\section{Perkembangan Modal}

Sebelum peneliti menyajikan perhitungan tentang peramalan perkembangan modal terlebih dahulu akan disajikan perkembangan modal koperasi Baitul Maal wat Tamwil Seruyan Sejahtera. Untuk melihat 
perkembangan Koperasi Baitul Maal wat Tamwil Seruyan Sejahtera harus melihat terlebih dahulu sumber modalnya. Sumber modal tersebut dapat dilihat dari tabel 3 berikut ini:

Tabel 3. Sumber modal koperasi Baitul Maal wat Tamwil Seruyan Sejahtera dari tahun 2012-2016.

\begin{tabular}{|c|c|c|c|}
\hline No & Tahun & Sumber modal & Jumlah \\
\hline \multirow[t]{8}{*}{1} & 2012 & Simpanan pokok & $240.000,00$ \\
\hline & & Simpanan wajib & $834.000,00$ \\
\hline & & Simpanan penyertaan & $\operatorname{Rp} 149.706 .000,00$ \\
\hline & & Laba-rugi / SHU ditahan & $\mathrm{Rp} \quad-1.174 .862,00$ \\
\hline & & Laba-rugi / SHU tahun berjalan & Rp $42.138 .486,00$ \\
\hline & & Laba-rugi / SHU bulan & $5.922 .492,00$ \\
\hline & & Desember 2012 & \\
\hline & & Jumlah & Rp 197.666.116,00 \\
\hline \multirow[t]{8}{*}{2} & 2013 & Simpanan pokok & $420.000,00$ \\
\hline & & Simpanan wajib & $1.224 .000,00$ \\
\hline & & Simpanan penyertaan & Rp 157.306.000,00 \\
\hline & & Modal sendiri & Rp $11.721 .529,00$ \\
\hline & & Laba-rugi / SHU tahun berjalan & Rp $52.932 .602,00$ \\
\hline & & Laba-rugi / SHU bulan & $3.205 .201,00$ \\
\hline & & Desember 2013 & \\
\hline & & Jumlah & Rp 226.809.332,00 \\
\hline \multirow[t]{8}{*}{3} & 2014 & Simpanan pokok & $470.000,00$ \\
\hline & & Simpanan wajib & $1.224 .000,00$ \\
\hline & & Simpanan penyertaan & $\operatorname{Rp} 82.740 .000,00$ \\
\hline & & Modal sendiri & Rp $11.721 .529,00$ \\
\hline & & Laba-rugi / SHU tahun berjalan & Rp $80.340 .503,00$ \\
\hline & & Laba-rugi / SHU bulan & Rp $\quad 12.796 .342,00$ \\
\hline & & Desember 2014 & \\
\hline & & Jumlah & Rp 189.292.375,00 \\
\hline \multirow[t]{6}{*}{4} & 2015 & Simpanan pokok & $507.000,00$ \\
\hline & & Simpanan wajib & $1.844 .000,00$ \\
\hline & & Simpanan penyertaan & Rp $154.740 .000,00$ \\
\hline & & Modal sendiri & $3.513 .108,00$ \\
\hline & & Laba-rugi / SHU tahun berjalan & Rp 105.108.861,00 \\
\hline & & Jumlah & Rp 293.775.969,00 \\
\hline \multirow[t]{6}{*}{5} & 2016 & Simpanan pokok & $523.000,00$ \\
\hline & & Simpanan wajib & Rp $\quad 1.921 .000,00$ \\
\hline & & Simpanan penyertaan & Rp $172.481 .763,00$ \\
\hline & & Modal sendiri & Rp $15.446 .000,00$ \\
\hline & & Laba-rugi / SHU & Rp $122.626 .780,00$ \\
\hline & & Jumlah & Rp 312.998.543,00 \\
\hline
\end{tabular}

Sumber Data : Koperasi Baitul Maal Wat Tamwil Seruyan Sejahtera.

Berdasarkan tabel 3 dapat diolah tabel modal Koperasi Baitul Maal Wat Tamwil Seruyan Sejahtera dari tahun 2012-2016 pada tabel 4 berikut ini:

Tabel4. Modal Koperasi Baitul Maal Wat Tamwil Seruyan Sejahtera tahun 2012-2016

\begin{tabular}{ccc}
\hline No & Tahun & Modal \\
\hline 1 & 2012 & $\operatorname{Rp~197.666.116,00~}$ \\
2 & 2013 & $\operatorname{Rp~226.809.332,00~}$ \\
3 & 2014 & $\operatorname{Rp~} 189.292 .374,00$ \\
4 & 2015 & $\operatorname{Rp~293.775.969,00}$ \\
5 & 2016 & $\operatorname{Rp~312.998.543,00~}$ \\
\hline
\end{tabular}

Sumber : data diolah dari tabel 3.
Berdasarkan tabel 4 di atas dapat dihitung perkembangan modal Koperasi Baitul Maal Wat Tamwil Seruyan Sejahtera dengan menggunakan rumus Growth.

Angka-angka perhitungan modal Koperasi Baitul Maal wat Tamwil Seruyan Sejahtera tahun 2012-2016 akan terlihat lebih jelas pada tabel 5 di halaman berikut ini:

Tabel5. Perkembangan modal Koperasi Baitul Maal wat Tamwil Seruyan Sejahtera tahun 2012-2016.

\begin{tabular}{|c|c|c|c|c|c|}
\hline No & Thn & $\begin{array}{c}\text { Jumlah } \\
\text { Anggota }\end{array}$ & Modal & Perkembangan & Persentase \\
\hline 1 & 2012 & 07 & $\begin{array}{c}\mathrm{Rp} \\
197.666 .116,00\end{array}$ & - & - \\
\hline 2 & 2013 & 14 & $\begin{array}{c}\mathrm{Rp} \\
226.809 .332,00\end{array}$ & $\begin{array}{c}\mathrm{Rp} \\
29.149 .216,00\end{array}$ & $15 \%$ \\
\hline 3 & 2014 & 18 & $\begin{array}{c}\mathrm{Rp} \\
189.292 .374,00\end{array}$ & $\begin{array}{c}\text { Rp- } \\
37.522 .957,00\end{array}$ & $-17 \%$ \\
\hline 4 & 2015 & 36 & $\begin{array}{c}\mathrm{Rp} \\
265.713 .969,00\end{array}$ & $\begin{array}{c}\mathrm{Rp} \\
76.421 .594,00\end{array}$ & $40 \%$ \\
\hline 5 & 2016 & 42 & $\begin{array}{c}\mathrm{Rp} \\
312.998 .543,00\end{array}$ & $\begin{array}{c}\mathrm{Rp} \\
47.284 .574,00\end{array}$ & $16 \%$ \\
\hline \multicolumn{3}{|c|}{ Rata-rata perkembangan } & & & $9,62 \%$ \\
\hline
\end{tabular}

Sumber: Data yang telah diolah dari tabel 4

Berdasarkan analisis pada tabel 5 dapat dilihat pada tahun 2013 terjadi pertumbuhan sebesar $15 \%$, tapi terjadi penurunan pada tahun 2014 sebesar 16\% disebabkan oleh menurunnya simpanan penyertaan / simpanan sukarela anggota. Pertumbuhan yang sangat meningkat pada tahun 2015 yaitu sebesar $40 \%$ yang terpengaruh oleh pertambahan anggota. Sedangkan pertumbuhan pada tahun 2016 hanya 16\%. Rata-rata pertumbuhan modal Koperasi Baitul Maal wat Tamwil Seruyan Sejahtera tahun 2012-2016 yaitu sebesar 9,62\%. Dapat disimpulkan bahwa pertumbuhan modal Koperasi Baitul Maal wat Tamwil Seruyan Sejahtera tidak stabil terpengaruh oleh jumlah pertambahan anggota baru dan simpanan sukarela dari anggota koperasi yang tidak menentu.

\section{Ramalan Perkembangan Modal}

Peramalan (taksiran) terhadap permodalan dilakukan dengan data time series (dari waktu ke waktu). Kegunaan dari pada analis time series ini adalah untuk mempelajari perkembangan permodalan untuk 
masa-masa yang akan datang. Peramalan dilakukan dengan membuat fungsi garis lurus (trand), dengan menggunakan metode Trend Least Square dengan rumus:

$$
\mathrm{Y}=\mathrm{a}+\mathrm{bX}
$$

Cara perhitungan peramalan modal Koperasi Baitul Maal wat Tamwil Seruyan Sejahtera dapat dilihat pada tabel berikut ini:

Tabel6. Perhitungan peramalan modal Koperasi Baitul Maal wat Tamwil Seruyan Sejahtera 2017-2021

\begin{tabular}{ccccc}
\hline Tahun & Y & $\mathbf{X}$ & $\mathbf{X Y}$ & $\mathbf{X}^{2}$ \\
\hline 2012 & Rp 197.666.116,00 & -2 & -395.332 .232 & 4 \\
2013 & Rp 226.809.332,00 & -1 & -226.815 .332 & 1 \\
2014 & Rp 189.292.374,00 & 0 & 0 & 0 \\
2015 & Rp 265.713.969,00 & 1 & 265.713 .969 & 1 \\
2016 & Rp 312.998.543,00 & 2 & 619.997 .086 & 4 \\
Jumlah & Rp 1.189.480.335,00 & & 263.563 .491 & 10 \\
\hline
\end{tabular}

Sumber: data yang sudah diolah dari tabel

Persamaan Trend Least Square: $\mathrm{Y}=\mathrm{a}+\mathrm{bX}$ Rumus tersebut disederhanakan :

$$
\begin{aligned}
& \mathrm{a}=\frac{\Sigma \mathrm{Y}}{\mathrm{N}} \\
& \mathrm{b}=\frac{\Sigma \mathrm{XY}}{\Sigma \mathrm{X}^{2}}
\end{aligned}
$$

Dari tabel 3 tersebut dapat diketahui:

$$
\begin{aligned}
\Sigma \mathrm{Y} & =1.189 .480 .335 \\
\Sigma \mathrm{XY} & =263.563 .491 \\
\Sigma \mathrm{X}^{2} & =10 \\
\mathrm{n} & =5
\end{aligned}
$$

Maka dapat dihitung persamaan Trend:

$$
\begin{aligned}
& \mathrm{a}=\frac{\Sigma \mathrm{Y}}{\mathrm{N}}=\frac{1.189 .480 .335}{5}=237.896 .067 \\
& \mathrm{~b}=\frac{\Sigma \mathrm{XY}}{\Sigma \mathrm{X}^{2}}=\frac{263.563 .491}{10}=26.356 .349,1
\end{aligned}
$$

Jadi persamaan trend : $\mathrm{Y}=237.897 .267$ $+26.356 .349,1 \mathrm{X}$

Hasil $b=26.356 .349,1$ berarti bahwa setiap tahun secara rata-rata terjadi kenaikan modal usaha terbesar $\mathrm{Rp}$ 26.356.349,10 dengan memasukkan barometer X (pengganti waktu) secara berturut-turut pada persamaan trend tersebut, yaitu parameter 6, 7, 8, 9 dan 10 maka dapat diketahui nilai trend taksiran modal untuk lima tahun ke depan yaitu tahun 2017-2021.

Dengan demikian diperoleh ramalan taksiran modal seperti perhitungan berikut ini:

$$
\begin{aligned}
\text { Y2017 } & =237.896 .067+26.356 .349,1(6) \\
& =396.034 .161,6 \\
\text { Y } 2018 & =237.896 .067+26.356 .349,1(7) \\
& =422.390 .510,7 \\
\text { Y } 2019 & =237.896 .067+26.356 .349,1(8) \\
& =448.746 .859,8 \\
\text { Y } 2020 & =237.896 .067+26.356 .349,1 \quad(9) \\
& =475.103 .208,9 \\
\text { Y } 2021 & =237.896 .067+26.356 .349,1(10) \\
& =501.459 .558
\end{aligned}
$$

Angka-angka perhitungan tersebut untuk lebih jelasnya dapat dilihat pada tabel 7 berikut ini.

Tabel7. Ramalan perkembangan modal Koperasi Baitul Maal wat Tamwil Seruyan Sejahtera 2017-2021

\begin{tabular}{ccc}
\hline No & Tahun & $\begin{array}{c}\text { Ramalan Perkembangan } \\
\text { Modal }\end{array}$ \\
\hline 1 & 2017 & Rp 396.034.161,60 \\
2 & 2018 & Rp 422.390.510,70 \\
3 & 2019 & Rp 448.746.859,80 \\
4 & 2020 & Rp 475.103.208,90 \\
\hline
\end{tabular}

Sumber: data telah diolah dari tabel 3

Berdasarkan tabel 7 tersebut dapat dilihat bahwa hasil ramalan perkembangan modal pada koperasi Baitul Maal wat Tamwil Seruyan Sejahtera pada tahun 2017 sebesar Rp 396.035.361,60, tahun 2018 sebesar Rp 422.391.710,70, tahun 2019 sebesar Rp 448.748.059,80, tahun 2020 sebesar Rp 475.104.408,90 dan tahun 2021 sebesar Rp 501.460.758,00. Ramalan perkembangan ini cenderung makin meningkat dari tahun ke tahun yaitu sebesar $\mathrm{Rp}$ 26.356.349,10. Peningkatan ini terpengaruh dari usaha yang dijalankan, penambahan anggota baru serta oleh sumbangan sukarela dari anggota. 


\section{PENUTUP}

\section{Simpulan}

Berdasarkan uraian serta hasil dan pembahasan yang telah disajikan pada babbab sebelumnya maka dapat ditarik kesimpulan sebagai berikut:

Perkembangan modal Koperasi Baitul Maal wat Tamwil Seruyan Sejahtera berdasarkan analisis pada tabel 5 dapat dilihat pada tahun 2013 terjadi pertumbuhan sebesar $15 \%$, tapi terjadi penurunan pada tahun 2014 sebesar $17 \%$ disebabkan oleh menurunnya simpanan penyertaan / simpanan sukarela anggota. Pertumbuhan yang sangat meningkat pada tahun 2015 yaitu sebesar $40 \%$ yang terpengaruh oleh pertambahan anggota. Sedangkan pertumbuhan pada tahun 2016 hanya 16\%. Rata-rata pertumbuhan modal Koperasi Baitul Maal wat Tamwil Seruyan Sejahtera tahun 2012-2016 yaitu sebesar 9,62\%. Pertumbuhan modal Koperasi Baitul Maal wat Tamwil Seruyan Sejahtera tidak stabil terpengaruh oleh jumlah pertambahan anggota baru dan simpanan sukarela dari anggota koperasi yang tidak menentu.

1. Hasil ramalan perkembangan modal koperasi Baitul Maal wat Tamwil Seruyan Sejahtera dari tahun 2017-2021 yaitu: Tahun 2017 sebesar Rp 396.034.161,60 Tahun 2018 sebesar Rp 422.390.510,70 Tahun 2019 sebesar Rp 448.746.859,80 Tahun 2020 sebesar Rp 475.103.208,90 Tahun 2021 sebesar Rp 501.459.558,00

2. Peningkatan modal koperasi Baitul Maal wat Tamwil Seruyan Sejahtera untuk tahun 2017-2021 menunjukkan tren yang meningkat sebesar Rp 26.356.349,10.

\section{Saran}

Setelah penulis memperoleh kesimpulan di atas, maka saran yang dapat dikemukakan adalah sebagai berikut: hendaknya setiap anggota dapat meningkatkan jumlah simpanan untuk menambah modal usaha; hendaknya pengurus mengembangkan unit usaha baru seperti membuat usaha produksi kerupuk, memberikan pinjaman modal kepada anggota yang ingin membuka sebuah usaha sendiri, agar modal dapat berkembang dengan memperhatikan kebutuhan anggota; hendaknya pengawas melakukan audit dan merevisi program kerja demi kelangsungan hidup koperasi; hasil analisis yang telah penulis kemukakan hendaknya dapat menjadi bahan pertimbangan perluasan usaha.

\section{DAFTAR PUSTAKA}

Abdillah, Willy., Jogiyanto. (2015). Partial Least Square (PLS) Alternatif Structural Equation Modeling (SEM) dalam Penelitian Bisnis. Ed.1. Yogyakarta:ANDI.

Firdaus, Muhammad dkk. (2004). Perkoperasian, Sejarah, Teori dan Praktik. Bogor: Penerbit Ghalia Indonesia.

Hendrojogi. (2004). Koperasi: Asas-asas, Teori, dan Praktik. Edisi Empat. Jakarta: PT. Raja Grafindo Persada.

Hasibuan, Malayu. (2012). Manajemen Sumber Daya Manusia. Jakarta: PT. Bumi Aksara.

Sudarsono dan Edilius. (2004). Koperasi dalam Teori dan Praktek. Jakarta: PT. Rineka.

Sutantya Rahardja Hadhikusuma. (2005). Hukum Koperasi Indonesia, Jakarta: Rajawali Pers.

Subandi. (2009). Ekonomi Koperasi Teori dan Praktik. Bandung: Alfabeta.

Sugiyono. (2013). Metode Penelitian Kuantitatif, Kualitatif, dan R\&D. Bandung: CV. Alfabeta.

Widiayanti, Ninik dan Sunindhia. (2008). Koperasi Dan Perekonomian Indonesia. Jakarta: Rineka Cipta. 